\title{
Aplikasi Dosis Pupuk Urea dan Umur Bibit terhadap Pertumbuhan dan Hasil Tanaman Padi Ketan (Oryza sativa glutinous L.)
}

\author{
Sunawan $^{1^{*}}$, dan Sugiarto ${ }^{1}$ \\ ${ }^{1}$ Program Studi Agroteknologi, Fakultas Pertanian, Universitas Islam Malang \\ JI. MT. Hatyonoo No. 193 Malang 65144, Jawa Timur, Indonesia \\ Email korespondensi: sunawan@unisma.ac.id
}

\begin{abstract}
Abstrak
Produktivitas padi ketan masih rendah meskipun potensi produksinya sangat tinggi. Hal ini dikarenakan teknologi khusus untuk budidaya padi ketan belum ada. Oleh karena itu diperlukan teknik budidaya yang mampu meningkatkan produksi tanaman padi ketan. Aplikasi dosis pupuk urea dan umur bibit diharapkan mampu untuk meningkatkan produksi tanaman padi ketan. Penelitian ini bertujuan untuk mendapatkan dosis pupuk urea dan umur bibit yang tepat yang mampu meningkatkan produksi tanaman padi ketan. Penelitian dirancang dengan menggunakan Rancangan Petak Terbagi disusun dengan Rancangan Acak Kelompok, 2 faktor (3x3). Sebagai Petak Utama (PU) adalah dosis pupuk urea $(P)$, terdiri dari 3 level: $P_{1}=100 \mathrm{~kg} \mathrm{ha}^{-1}, \mathrm{P}_{2}$ $=200 \mathrm{~kg} \mathrm{ha}^{-1}$ dan $P_{3}=300 \mathrm{~kg} \mathrm{ha}^{-1}$. Sebagai Anak Petak (AP) adalah Umur bibit (U), terdiri dari 3 level: $U_{1}=14$ hari, $U_{2}=21$ hari, dan $U_{3}=28$ hari. Variabel yang diamati tinggi tanaman, jumlah anakan, jumlah daun, luas daun, jumlah malai per rumpun, panjang malai, jumlah gabah, jumlah gabah bernas, jumlah gabah hampa, jumlah biji per malai, bobot segar, bobot kering, bobot 1000 butir, dan bobot gabah per hektar. Hasil penelitian menunjukkan bahwa dosis pupuk urea $300 \mathrm{~kg} \mathrm{ha}^{-1}\left(\mathrm{P}_{3}\right)$ dan umur bibit 14 hari $\left(U_{1}\right)$ memperlihatkan respon yang cukup baik, hasil ini menyarankan bahwa untuk meningkatkan produktivitas padi ketan perlu dosis pupuk urea $300 \mathrm{~kg} \mathrm{ha}^{-1}\left(\mathrm{P}_{3}\right)$ dan umur transplanting bibit 14 hari $\left(\mathrm{U}_{1}\right)$.
\end{abstract}

Kata Kunci: Padi ketan, dosis pupuk urea, umur bibit

\begin{abstract}
Nowadays glutinous rice productivity is still low even though its production potential is very high. It is caused by the lackness of special technology for glutinous rice cultivation. Therefore we need cultivation techniques that can increase the production of glutinous rice plants. Application of urea fertilizer in a proper dosage and a proper seedlings age are expected to be able to increase glutinous rice production. This study aimed to get the right dosage of urea fertilizer and the proper age seedlings that can increase glutinous rice production. The study was designed using a Divided Plot Design arranged by Randomize Block Design, 2 factors $(3 \times 3)$. As Main Plot (PU) was the dosage of urea fertilizer $(P)$, consisting of 3 levels: $P 1=100 \mathrm{~kg} \mathrm{ha}^{-1}, \mathrm{P} 2=200$ $\mathrm{kg} \mathrm{ha}^{-1}$ and $\mathrm{P} 3=300 \mathrm{~kg} \mathrm{ha}^{-1}$. As the plots (AP) were the age of seeds $(\mathrm{U})$, consisting of 3 levels: $U 1=14$ days, $U 2=21$ days, and $U 3=28$ days. Variables observed were plant height, number of tillers, number of leaves, leaf area, number of panicles per clump, panicle length, number of grains, number of grained rice, number of empty grains, number of seeds per panicle, fresh weight, dry weight, weight of 1000 grains, and grain weight per hectare. The results showed that the dosage of $300 \mathrm{~kg}$ ha-1 Urea (P3) and 14 days seedling ages (U1) showed a good response, so it can be recommended to be applied by the farmers.
\end{abstract}

Keywords: Glutinous rice, urea fertilizer dosage, seedling age 


\section{Pendahuluan}

Indonesia sebagai negara agraris mempunyai banyak sumber bahan baku, salah satunya yang cukup banyak adalah beras ketan putih (Oryza sativa glutionus L.). Beras ketan merupakan tanaman yang berasal dari Asia yang kini sudah tersebar luas ke seluruh dunia, termasuk Indonesia. Di beberapa negara seperti Laos dan Thailand beras ketan digunakan sebagai makanan pokok, dikarenakan kandungan karbohidratnya yang tinggi (Haryadi, 2006).

Pemberian pupuk adalah usaha untuk dapat meningkatkan produktivitas padi, diantaranya pupuk organik ataupun pupuk anorganik (Nurhayati et al., 1986). Dalam meningkatkan produktivitas, usaha yang banyak dilakukan selain pemberian pupuk organik adalah pupuk urea. Manfaat pupuk urea dapat memperbaiki pertumbuhan vegetatif tanaman (Hardjowigeno, 1987). Hasil produksi budidaya padi dipengaruhi oleh penggunaan sistem tanam yang tepat. Tidak menyangkut masalah sistem tanam, tetapi juga penggunaan varietas unggul (Aruan dan Rita, 2010). Produksi padi ditentukan oleh berbagai aspek, termasuk umur bibit tanaman padi. Untuk menghasilkan produksi yang tinggi maka perlu bibit bibit varietas unggul dengan pengelolaan yang baik sejak awal agarmampu menhadapi persaingan dan hambatan di lapangan (Djafar, 2002).

Menurut penelitian Meta (2006) tanaman padi (Oryza sativa L.), jika jumlah daun tanaman empat helai maka bibit siap untuk ditanam. Pembetukan anakan dapat mencapai titik optimal jika pindah tanam dilakukan ketika bibit masih muda 10 HSS, 15 HSS, atau 21 HSS. Pindah tanam yang terlalu lama (tanaman berumur lebih dari 21 HSS) menyebabkan tanaman menjadi tumbuh secara tidak optimal yang pada akhirnya dapat menurunkan hasil tanaman. Di dukung penelitian Vavrina (1998), tanaman akan cepat memasuki masa generatif dan lebih cepat menua ketika pindah tanam umur bibit terlambat, karena tanaman tidak mempunyai waktu untuk menyelesaikan pertumbuhan masa vegetatifnya. Pertumbuhan vegetatif tidak terhambat dan dapat tumbuh dengan baik jika pindah taman umur bibit lebih dini karena tanaman dapat beradatapsi terhadap lingkungan lebih cepat.

Penelitian ini bertujuan untuk mengetahui pengaruh dosis pupuk urea terhadap pertumbuhan dan hasil tanaman padi ketan, dan mengetahui pengaruh umur transplanting bibit terhadap pertumbuhan dan hasil tanaman padi ketan. Hipotesis dalam penelitian ini adalah pemberian dosis pupuk urea $300 \mathrm{~kg} / \mathrm{ha}$ dapat meningkatkan pertumbuhan dan hasil tanaman padi ketan, umur transplanting bibit padi ketan 14 hari dapat meningkatkan pertumbuhan dan hasil tanaman padi ketan, 
dan kombinasi perlakuan pemberian dosis pupuk urea $300 \mathrm{~kg} / \mathrm{ha}$ dan umur transplanting 14 hari setelah semai dapat meningkatkan pertumbuhan dan hasil tanaman padi ketan.

\section{Bahan dan Metode}

Penelitian dilaksanakan pada bulan September 2016 sampai Februari 2017 di Desa Kepuharjo, Kecamatan Karangploso, Kabupaten Malang, Jawa Timur, Indonesia. Kepuharjo memiliki ketinggian 500 m dpl; 7.9 Lintang Selatan dan 112,6o Bujur Timur.

Penelitian ini menggunakan Rancangan Petak Terbagi (RPT) yang disusun dengan Rancangan Acak Kelompok (RAK) 2 faktor (3×3). Petak utama (PU) adalah dosis pupuk urea $(P)$, terdiri dari 3 level: $P_{1}=$ Dosis Pupuk Urea $100 \mathrm{~kg} \mathrm{ha}^{-1}, \mathrm{P} 2=$ Dosis Pupuk Urea $200 \mathrm{~kg} \mathrm{ha}^{-1}$, dan $\mathrm{P}_{3}=$ Dosis Pupuk Urea $300 \mathrm{~kg} \mathrm{ha}^{-1}$. Anak Petak $(A P)$ adalah Umur bibit $(U)$ terdiri dari 3 level: $U_{1}=$ Umur bibit 14 hari, $U_{2}=$ Umur bibit 21 hari, dan $\mathrm{U}_{3}=$ Umur bibit 28 hari. Sehingga terdapat jumlah perlakuan 9 kominasi perlakuan, masing-masing perlakuan diulang 3 kali.

Persiapan lahan dilakukan dengan traktor tangan dua kali hingga tanah berbentuk lumpur. Kemudian dibuat ukuran plot eksperimental 3,0 x 2,0 m dengan 9 plot. Bibit ditanam sesuai perlakuan (umur 14 hari, 21 hari dan 28 hari) dengan jarak tanam 0,20 $\mathrm{m} \times 0,20 \mathrm{~m}$. Pada umur 7 hari setelah tanam (hst), tanaman dipupuk dengan $75 \mathrm{~kg} \mathrm{P}_{2} \mathrm{O}_{5}$ (dalam bentuk SP-36) dan $50 \mathrm{~kg} \mathrm{~K} 2 \mathrm{O}$ (dalam bentuk $\mathrm{KCl}$ ) per ha. Pupuk nitrogen, dalam bentuk urea menurut perlakuan (45, 90, 135 dan $180 \mathrm{~kg} \mathrm{ha}^{-1}$ ), diterapkan 3 kali, pada 10, 20 dan 30 hst, masing-masing pada 20, 50 dan 30\%. Penyiangan dilakukan secara manual pada 7, 14, dan 21 hst. Pengendalian hama dilakukan sesuai dengan kondisi serangan hama. Sampling destruktif dilakukan pada 28, 35, 49, 63 dan 77 hst. Pengukuran luas daun dilakukan pada daun yang sedikit lebih tua (4 daun per tanaman).

Data yang diperoleh dianalisa dengan analisa ragam 5\% dan apabila terdapat pengaruh dilanjutkan dengan uji Duncan 5\% untuk melihat perbedaan antar perlakuannya.

\section{Hasil dan Pembahasan}

\section{Tinggi Tanaman}

Terdapat interaksi antara perlakuan dosis pupuk urea dan umur bibit terhadap tinggi tanaman pada umur 63 hst (Gambar 1). Gambar 1 memperlihatkan bahwa terdapat interaksi antara perlakuan dosis pupuk urea dan umur bibit pada jumlah anakan. Hal ini menunjukkan bahwa ada pengaruh antara pemberian dosis pupuk urea 
dan umur bibit yang berbeda terhadap jumlah anakan tanaman padi ketan. $U_{1}$ (14 hari) dan $U_{2}$ (21 hari) mengikuti pola linear artinya semakin meningkat dosis pupuk urea yang diberikan maka jumlah anakan tanaman akan semakin meningkat. Sedangkan $\cup_{3}$ (28 hari) mengikuti pola kuadratik artinya semakin tinggi interval pemberian dosis pupuk urea pada tingkat tertentu akan menghasilkan jumlah anakan yang tinggi, namun jika melampaui titik tersebut jumlah anakan akan menurun. Semakin tua umur bibit kemampuan untuk membentuk anakan semakin menurun dibandingkan bibit brumut muda meskipun dosis pupuk ditingkatkan. Secara terpisah masing-masing perlakuan menunjukkan perbedaan yang nyata seperti yang di tunjukkan oleh Tabel 1.

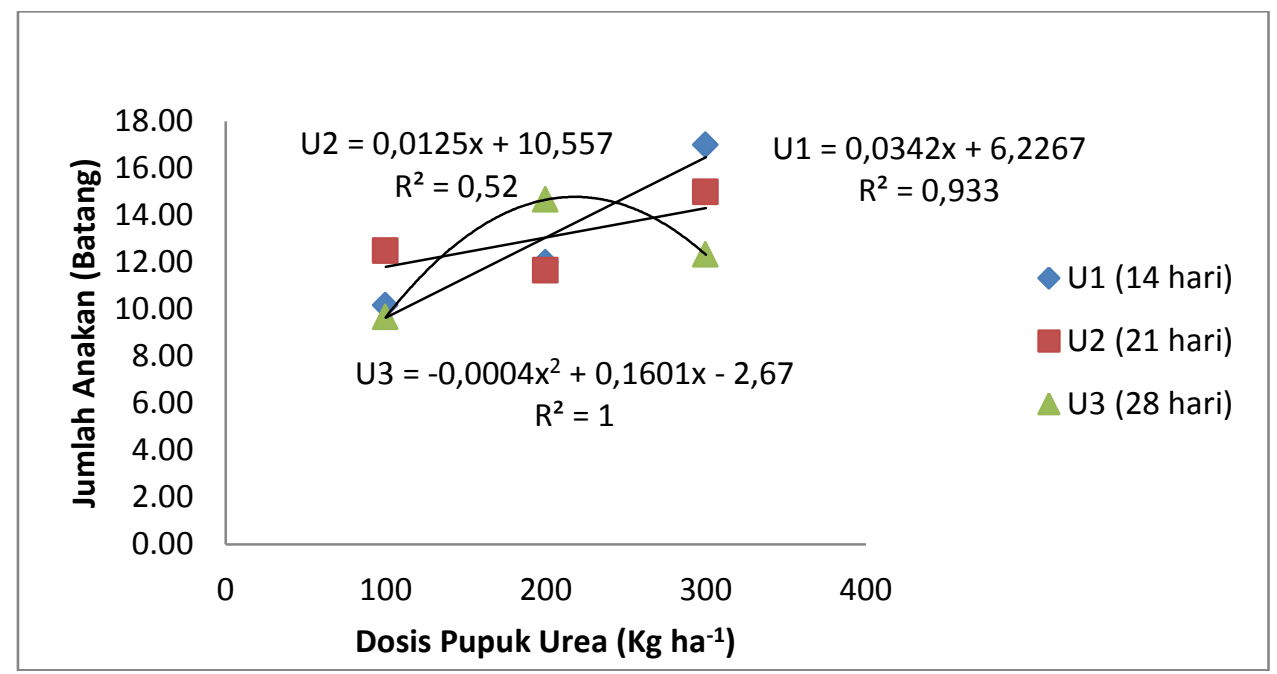

Gambar 1. Interaksi Dosis Pupuk Urea dengan Umur Bibit terhadap Jumlah Anakan Umur 63 hst.

Tabel 1 memperlihatkan bahwa perlakuan dosis pupuk urea berbeda nyata terhadap tinggi tanaman umur 70 dan 77 hst, sedangkan perlakuan umur bibit berbeda nyata terhadap tinggi tanaman umur 35 hst. Tinggi tanaman pada perlakuan dosis pupuk urea $\mathrm{P}_{3}\left(300 \mathrm{~kg} \mathrm{ha}{ }^{-1}\right)$ dan perlakuan umur transplanting bibit $\mathrm{U}_{3}$ (28 hari) memperlihatkan tinggi tanaman terbesar. Apabila tanaman diberi pupuk urea semakin banyak akan semakin meningkat pula pertumbuhan tanaman. Hal ini didukung dengan penelitian Putra, (2012) menyatakan bahwa pemberian pupuk baik itu jenis atau takaran pemupukan sangat mempengaruhi respons tanaman padi sehingga berdampak terhadap pertumbuhan padi khususnya pada tinggi tanaman

Tabel 1. Rata-rata Tinggi Tanaman pada Perlakuan Dosis Pupuk Urea dan Umur Transplanting Bibit 


\begin{tabular}{ccccccccc}
\hline $\begin{array}{c}\text { Dosis Pupuk Urea } \\
\left(\mathrm{kg} \mathrm{ha}^{-1}\right)\end{array}$ & 28 & 35 & 42 & 49 & 56 & 63 & 70 & 77 \\
\hline 100 & 36,78 & 55,11 & 64,89 & 73,17 & 81,06 & 82,89 & $95,50 \mathrm{a}$ & $\begin{array}{c}106,33 \\
\mathrm{a}\end{array}$ \\
200 & 37,38 & 54,33 & 57,72 & 77,17 & 85,44 & 88,00 & $99,11 \mathrm{~b}$ & $\begin{array}{c}110,94 \\
\mathrm{~b}\end{array}$ \\
300 & 36,61 & 57,44 & 68,28 & 75,78 & 86,44 & 90,28 & $101,67 \mathrm{c}$ & $112,22 \mathrm{c}$ \\
\hline Uji Duncan 5\% & $\mathrm{TN}$ & $\mathrm{TN}$ & $\mathrm{TN}$ & $\mathrm{TN}$ & $\mathrm{TN}$ & $\mathrm{TN}$ & $\mathrm{N}$ & $\mathrm{N}$ \\
\hline Umur Bibit (hari) & & & & & & & & \\
\hline 14 & 36,11 & $\begin{array}{c}57,89 \\
\mathrm{~b}\end{array}$ & 68,50 & 76,50 & 85,61 & 88,72 & 100,94 & 108,94 \\
21 & 34,66 & $\begin{array}{c}51,78 \\
\mathrm{a}\end{array}$ & 56,50 & 74,78 & 82,00 & 86,11 & 96,00 & 108,94 \\
28 & 40,00 & $\begin{array}{c}57,22 \\
\mathrm{~b}\end{array}$ & 65,89 & 74,83 & 85,33 & 86,33 & 99,33 & 111,61 \\
\hline Uji Duncan 5\% & TN & $\mathrm{N}$ & TN & TN & TN & TN & TN & TN
\end{tabular}

Keterangan: - N : Nyata. - TN : Tidak nyata, hst $=$ hari setelah tanam

\section{Jumlah Anakan}

Tidak terdapat interaksi antara perlakuan dosis pupuk urea dengan umur bibit terhadap jumlah anakan. Akan tetapi secara terpisah masing-masing perlakuan menunjukkan perbedaan yang nyata (Tabel 2). Tabel 2 memperlihatkan bahwa pada umur 42, 56, 70 dan 77 hst peningkatan dosis pupuk diikuti oleh peningkatan jumlah anakan. Perlakuan dosis urea $300 \mathrm{~kg} \mathrm{ha}^{-1}\left(\mathrm{P}_{3}\right)$ memberikan jumlah anakan tertinggi. Sedangkan pada umur 77 hst bahwa peningkatan umur bibit menurunkan jumlah anakan. Jumlah anakan pada perlakuan umur bibit 14 hari $\left(U_{1}\right)$ tidak berbeda nyata dengan perlakuan umur bibit 21 hari $\left(\mathrm{U}_{2}\right)$. Jumlah anakan terendah dicapai oleh perlakuan umur bibit 28 hast $\left(\mathrm{U}_{3}\right)$. Hal ini sesuai dengan yang diungkapkan oleh Gani (2003), bibit dengan umur yang muda akan mampu beradatapsi dengan lingkungan, dapat berkembang lebih baik dan anakan baru akan lebih seragam. 
Tabel 2. Rata-rata Jumlah Anakan pada Perlakuan Dosis Pupuk Urea dan Umur Transplanting Bibit

\begin{tabular}{|c|c|c|c|c|c|c|c|}
\hline \multirow{2}{*}{$\begin{array}{c}\text { Perlakuan } \\
\text { Dosis Pupuk Urea } \\
\left(\mathrm{kg} \mathrm{ha}^{-1}\right)\end{array}$} & \multicolumn{7}{|c|}{ Jumlah Anakan (batang) pada Umur (hst) } \\
\hline & 28 & 35 & 42 & 49 & 56 & 70 & 77 \\
\hline 100 & 4,39 & 9,67 & $11,67 \mathrm{a}$ & 11,44 & $12,17 \mathrm{a}$ & $10,50 \mathrm{a}$ & $9,11 \mathrm{a}$ \\
\hline 200 & 3,94 & 10,22 & $11,83 \mathrm{a}$ & 12,50 & $13,28 \mathrm{a}$ & $13,00 \mathrm{~b}$ & $11,44 \mathrm{~b}$ \\
\hline 300 & 4,44 & 12,50 & $15,50 \mathrm{~b}$ & 15,28 & $17,61 \mathrm{~b}$ & $14,61 \mathrm{c}$ & $14,17 \mathrm{c}$ \\
\hline Uji Duncan 5\% & $\mathrm{TN}$ & $\mathrm{TN}$ & $\mathrm{N}$ & TN & $\mathrm{N}$ & $\mathrm{N}$ & $\mathrm{N}$ \\
\hline \multicolumn{8}{|l|}{ Umur Bibit (hari) } \\
\hline 14 & 4,67 & 11,50 & 13,39 & 14,11 & 14,72 & 13,56 & $12,44 \mathrm{~b}$ \\
\hline 21 & 4,22 & 10,50 & 13,39 & 12,83 & 14,89 & 11,78 & $11,83 b$ \\
\hline 28 & 3,89 & 10,39 & 12,22 & 12,28 & 13,44 & 12,78 & $10,44 \mathrm{a}$ \\
\hline Uji Duncan 5\% & TN & TN & TN & TN & TN & TN & $\mathrm{N}$ \\
\hline
\end{tabular}

Keterangan: - N : Nyata. - TN : Tidak nyata, hst = hari setelah tanam

\section{Jumlah Daun}

Tidak terdapat interaksi antara perlakuan dosis pupuk urea dengan umur bibit terhadap jumlah daun. Akan tetapi secara terpisah masing-masing perlakuan menunjukkan perbedaan yang nyata terhadap peubah jumlah daun (Tabel 3). Tabel 3 memperlihatkan bahwa peningkatan dosis pupuk urea diikuti peningkatan jumlah daun pada umur 49, 56, 63 dan 77 hst, sedangkan pada perlakuan umur bibit menunjukkan bahwa peningkatan umur bibit menurunkan jumlah daun pada umur 49 dan 77 hst. Jumlah daun terbesar dicapai pada perlakuan dosis pupuk urea $300 \mathrm{~kg} \mathrm{ha}$ ${ }^{1}\left(\mathrm{P}_{3}\right)$. Pada perlakuan umur jumlah daun terendah dicapai pada perlakuan umur bibit28 hari $\left(\mathrm{U}_{3}\right)$. Hartadi (1997) mengemukakan bahwa pemupukan mempengaruhi pegmetasi daun, dan akan mempengaruhi jumlah energi yang akan diterima oleh tanaman untuk mempercepat penambahan jumlah daun. Fotosintesis menghasilkan karbohidrat yang akan digunakan untuk pertambahan jumlah daun tanaman. 
Tabel 3. Rata-rata Jumlah Daun pada Perlakuan Dosis Pupuk Urea dan Umur Bibit

\begin{tabular}{ccccccccc}
\hline $\begin{array}{c}\text { Perlakuan } \\
\text { Dosis Pupuk Urea } \\
\left(\mathrm{kg} \mathrm{ha}^{-1}\right)\end{array}$ & 28 & 35 & 42 & 49 & 56 & 63 & 70 & 77 \\
\cline { 2 - 9 } & 12,72 & 30,00 & 38,72 & $44,44 \mathrm{a}$ & $49,56 \mathrm{a}$ & $46,00 \mathrm{a}$ & 51,72 & $44,28 \mathrm{a}$ \\
200 & 11,33 & 28,94 & 39,67 & $49,22 \mathrm{~b}$ & $59,17 \mathrm{~b}$ & $59,72 \mathrm{~b}$ & 63,39 & $58,44 \mathrm{~b}$ \\
300 & 14,67 & 35,28 & 45,67 & $61,00 \mathrm{c}$ & $70,67 \mathrm{c}$ & $63,67 \mathrm{~b}$ & 72,22 & $69,50 \mathrm{c}$ \\
\hline Uji Duncan 5\% & TN & TN & TN & $\mathrm{N}$ & $\mathrm{N}$ & $\mathrm{N}$ & $\mathrm{TN}$ & $\mathrm{N}$ \\
\hline Umur Bibit (hari) & & & & & & & & \\
\hline 14 & 13,28 & 32,39 & 44,33 & $51,50 \mathrm{~b}$ & 61,39 & 57,39 & 64,17 & $62,61 \mathrm{~b}$ \\
21 & 12,61 & 32,11 & 41,56 & $58,33 \mathrm{c}$ & 62,22 & 58,61 & 61,94 & $56,78 \mathrm{ab}$ \\
28 & 12,83 & 29,72 & 38,17 & $44,83 \mathrm{a}$ & 55,78 & 53,39 & 61,22 & $52,83 \mathrm{a}$ \\
\hline Uji Duncan 5\% & TN & TN & TN & $\mathrm{N}$ & TN & TN & TN & $\mathrm{N}$ \\
\hline
\end{tabular}

Keterangan: - $\mathrm{N}$ : Nyata. - TN : Tidak nyata, hst $=$ hari setelah tanam

\section{Luas Daun}

Terdapat interaksi antara perlakuan dosis pupuk urea dan umur bibit terhadap peubah luas daun (Gambar 2). Gambar 2 memperlihatkan bahwa perlakuan $U_{1}$ (14 hari) mengikuti pola linear artinya semakin meningkat dosis pupuk urea yang diberikan maka luas daun akan semakin meningkat. Sedangkan $U_{2}$ (21 hari) dan $U_{3}$ (28 hari) mengikuti pola kuadratik artinya semakin tinggi interval pemberian dosis pupuk urea pada tingkat tertentu akan menghasilkan luas daun yang tinggi, namun jika melampaui titik tersebut luas daun akan menurun. Hal ini menunjukkan bahwa ada pengaruh antara pemberian dosis pupuk urea dan umur bibit yang berbeda terhadap luas daun tanaman padi ketan.

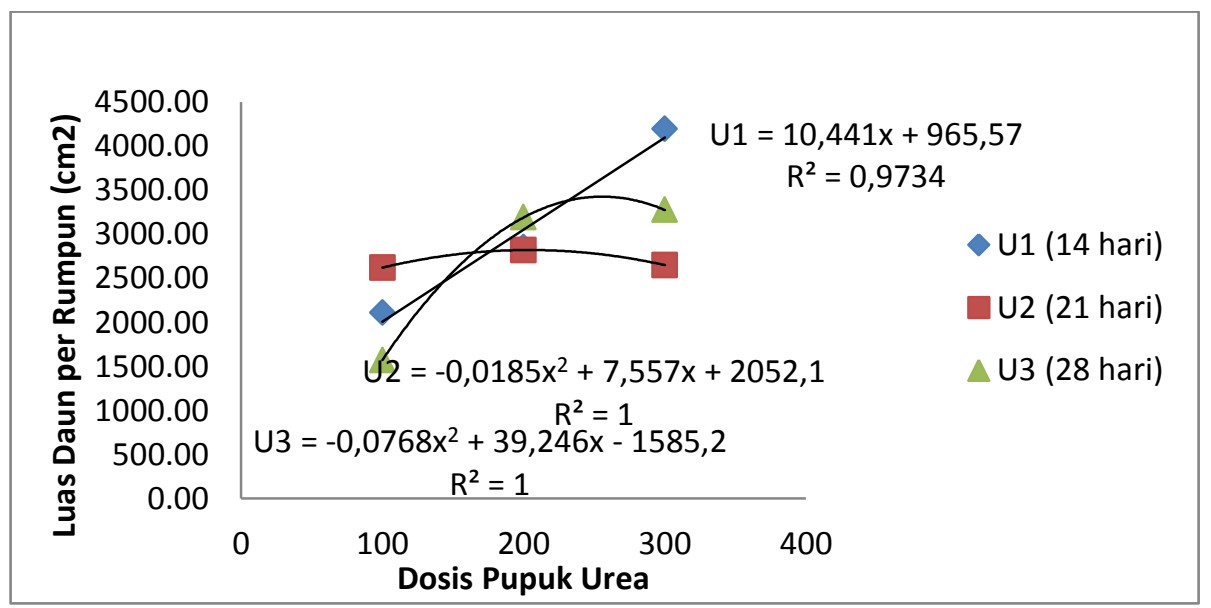

Gambar 2. Interaksi Dosis Pupuk Urea dengan Umur Bibit terhadap Luas Daun Umur 70 hst 
Secara terpisah masing-masing perlakuan menunjukkan perbedaan yang nyata terhadap peubah luas daun (Tabel 4). Tabel 4 memperlihatkan bahwa peningkatan dosis pupuk urea diikuti peningkatan luas daun pada umur 56, 63 dan 77 hst, sedangkan perlakuan umur bibit berbeda nyata terhadap luas daun umur $77 \mathrm{hst}$. Luas daun pada perlakuan dosis pupuk urea $\mathrm{P}_{3}\left(300 \mathrm{~kg}\right.$ urea.ha $\left.{ }^{-1}\right)$ memperlihatkan luas daun terbesar dan berbeda dengan perlakuan lainnya. Hal ini sesuai dengan yang diungkapkan Setyamidjaja (1986) bahwa pertumbuhan tinggi tanaman, jumlah anakan dan daun dapat dipercepat pertumbuhan jaringan tanamannya dengan memberi pupuk N, P, K. Sejalan dengan pendapat Hardjowigeno (1987) menyatakan bahwa memperbaiki pertumbuhan vegetatif dengam memberi sumber hara $\mathrm{N}$, salah satunya adalah pupuk urea, dimana tanaman akan berwarna lebih hijau jika tanaman tumbuh dengan kecukupan N. Umur bibit 14 hari memberikan nilai luas daun terbesar dan berbeda dengan perlakuan lainnya.

Tabel 4. Rata-rata Luas Daun pada Perlakuan Dosis Pupuk Urea dan Umur Transplanting Bibit.

\begin{tabular}{|c|c|c|c|c|c|c|c|}
\hline \multirow{2}{*}{$\begin{array}{c}\text { Perlakuan } \\
\text { Dosis Pupuk } \\
\text { Urea } \\
\left(\mathrm{kg} \mathrm{ha}^{-1}\right)\end{array}$} & \multicolumn{7}{|c|}{ Luas Daun $\left(\mathrm{cm}^{2}\right)$ pada Umur (hst) } \\
\hline & 28 & 35 & 42 & 49 & 56 & 63 & 77 \\
\hline 100 & 226,40 & 626,60 & 992,64 & 1313,50 & $1659,44 \mathrm{a}$ & $1639,36 \mathrm{a}$ & $1936,25 \mathrm{a}$ \\
\hline 200 & 201,01 & 664,78 & 1063,45 & 1586,31 & $2118,16 b$ & $2368,81 \mathrm{~b}$ & $2913,32 b$ \\
\hline 300 & 270,39 & 811,62 & 1204,30 & 2155,94 & $2672,38 \mathrm{c}$ & 2605,22 c & $3475,94 \mathrm{c}$ \\
\hline Uji Duncan 5\% & $\mathrm{TN}$ & $\mathrm{TN}$ & $\mathrm{TN}$ & TN & N & N & N \\
\hline \multicolumn{8}{|l|}{ Umur Bibit (hari) } \\
\hline 14 & 235,03 & 734,32 & 1179,12 & 1622,87 & 2312,24 & 2275,38 & $3180,37 b$ \\
\hline 21 & 221,30 & 680,94 & 1084,20 & 2020,42 & 2168,94 & 2300,06 & $2651,63 \mathrm{a}$ \\
\hline 28 & 241,47 & 687,73 & 997,07 & 1412,46 & 1968,80 & 2037,94 & $2493,51 \mathrm{a}$ \\
\hline Uji Duncan 5\% & $\mathrm{TN}$ & $\mathrm{TN}$ & $\mathrm{TN}$ & TN & $\mathrm{TN}$ & $\mathrm{TN}$ & $\mathrm{N}$ \\
\hline
\end{tabular}

\section{Bobot Kering Total Tanaman}

Tidak terjadi interaksi antara perlakuan dosis pupuk urea denga umur bibit terhadap bobot kering total tanaman, akan terapi secara terpisah masing-masing perlakuan terjadi perbedaaan yang nyata (Tabel5). Tabel 5 memperlihatkan bahwa peningkatan dosis pupuk urea hingga $300 \mathrm{~kg} \mathrm{ha}^{-1}$, diikuti peningkatkan bobot kering 
total tanaman padi ketan. Bobot kering total pada perlakuan dosis pupuk urea $300 \mathrm{~kg}$ $\mathrm{ha}^{-1}\left(\mathrm{P}_{2}\right)$ memperlihatkan bobot kering total terbesar.

Hal ini sesuai dengan yang diungkapkan Suwardi dan Roy (2009) yang menyatakan bahwa tinggi tanaman dipengaruhi dengan pemberian $\mathrm{N}$ yang semakin meningkat pada 42 hst dan bobot kering tanaman. Semakin besar pemberian N, tinggi tanaman dan bobot kering tanaman semakin besar, adanya hubungan tanaman dalam menyerap hara yang diberikan.

Tabel 5. Rata-rata Bobot Kering Total pada Perlakuan Dosis Pupuk Urea dan Umur Bibit.

\begin{tabular}{cccccc}
\hline $\begin{array}{c}\text { Perlakuan } \\
\text { Dosis Pupuk Urea } \\
\left(\mathrm{kg} \mathrm{ha}^{-1}\right)\end{array}$ & 35 & 49 & 63 & 77 & Panen \\
\cline { 2 - 6 } & 3,82 & 13,82 & $23,94 \mathrm{a}$ & $39,59 \mathrm{a}$ & 55,33 \\
200 & 3,31 & 13,77 & $25,54 \mathrm{a}$ & $45,57 \mathrm{~b}$ & 55,71 \\
300 & 2,98 & 14,33 & $33,89 \mathrm{~b}$ & $57,22 \mathrm{c}$ & 51,59 \\
\hline Uji Duncan 5\% & $\mathrm{TN}$ & $\mathrm{TN}$ & $\mathrm{N}$ & $\mathrm{N}$ & $\mathrm{TN}$ \\
\hline Umur Bibit (hari) & & & & & \\
\hline 14 & 3,38 & 15,09 & $31,15 \mathrm{~b}$ & 46,76 & 54,64 \\
21 & 3,13 & 13,04 & $23,52 \mathrm{a}$ & 50,04 & 56,14 \\
28 & 3,60 & 13,78 & $28,69 \mathrm{~b}$ & 45,58 & 51,84 \\
\hline Uji Duncan 5\% & $\mathrm{TN}$ & $\mathrm{TN}$ & $\mathrm{N}$ & $\mathrm{TN}$ & $\mathrm{TN}$ \\
\hline
\end{tabular}

Keterangan: - N : Nyata. - TN : Tidak nyata, hst : hari setelah tanam

\section{Komponen Hasil}

Tabel 6 memperlihatkan bahwa jumlah biji total, jumlah biji bernas, jumlah biji hampa, dan jumlah biji per malai tidak berbeda nyata terhadap dosis pupuk urea dan umur bibit. Interaksi perlakuan dosis pupuk urea dan umur bibit juga tidak berbeda nyata terhadap peubah tersebut. Jumlah biji total, jumlah biji bernas, jumlah biji hampa dan jumlah biji per malai pada perlakuan dosis pupuk $200 \mathrm{~kg} \mathrm{ha}^{-1}\left(\mathrm{P}_{2}\right)$ dan perlakuan umur bibit14 hari $\left(\mathrm{U}_{1}\right)$ memperlihatkan jumlah biji total terbesar. 
Tabel 6. Rata-rata Jumlah Biji Total, Jumlah Biji Bernas, Jumlah Biji Hampa dan Jumlah Biji per Malai pada Perlakuan Dosis Pupuk Urea dan Umur Bibit.

\begin{tabular}{ccccc}
\hline $\begin{array}{c}\text { Perlakuan } \\
\text { Dosis Pupuk Urea } \\
\left(\mathrm{kg} \mathrm{ha}^{-1}\right)\end{array}$ & $\begin{array}{c}\text { Jumlah Biji } \\
\text { Total (Butir) }\end{array}$ & $\begin{array}{c}\text { Jumlah Biji } \\
\text { Bernas (Butir) }\end{array}$ & $\begin{array}{c}\text { Jumlah Biji } \\
\text { Hampa (Butir) }\end{array}$ & $\begin{array}{c}\text { Jumlah Biji per } \\
\text { Malai (Butir) }\end{array}$ \\
\hline 100 & 1417,39 & 1258,44 & 275,56 & 139,54 \\
200 & 1691,89 & 1290,61 & 322,28 & 140,69 \\
300 & 1489,83 & 1237,67 & 271,44 & 129,31 \\
\hline Uji Duncan 5\% & TN & TN & TN & TN \\
\hline Umur Bibit (hari) & & & & 142,54 \\
\hline 14 & 1584,56 & 1316,67 & 294,33 & 137,73 \\
21 & 1485,89 & 1287,44 & 282,33 & 129,26 \\
\hline 28 & 1528,67 & 1182,61 & 292,61 & TN \\
\hline Uji Duncan 5\% & TN & TN & TN & \\
\hline
\end{tabular}

Keterangan: - TN : Tidak nyata.

\section{Bobot 1000 biji dan Bobot biji per hektar}

Tabel 7 memperlihatkan bahwa bobot 1000 biji dan bobot gabah per hektar tidak berbeda nyata terhadap dosis pupuk urea dan umur transplanting bibit. Interaksi perlakuan dosis pupuk urea dan umur bibit juga tidak berbeda nyata terhadap peubah tersebut. Hal ini menunjukkan bahwa peningkatan dosis pupuk urea dan umur bibit tidak diikuti oeh peningkatann kualitas dan kuatitas hasil gabah padi ketan. Hal ini diduga karena terdapat pengaruh dari faktor internal dan eksternal tanaman padi ketan. Sesuai dengan yang diungkapkan Harjadi (1983) menyatakan bahwa faktor internal dari tanaman serta faktor lingkungan lebih berbeda terhadap pertumbuhan dan produksi padi. Efisiensi penggunaan cahaya serta kompetisi tanaman satu dengan tanaman lainnya dalam menyerap unsur hara dan air memberi hasil yang berbeda dan pengaruh yang nyata. Didukung oleh Cepy dan Wayan (2011), faktor internal dan faktor ekternal mempengaruhi baik buruknya pertumbuhan dan hasil tanaman. Usia tanaman, morfologi tanaman, daya hasil, kapasitas menyimpan cadangan makanan, ketahanan terhadap penyakit dan lain-lain adalah faktor internal. Sedangkan iklim, tanah dan faktor biotik adalah faktor eksternal. Kedua faktor tersebut diduga menyebabkan pertumbuhan dan hasil yang diperoleh.

Hasil penelitian menunjukkan bahwa dosis pupuk urea $300 \mathrm{~kg} \mathrm{ha}^{-1}\left(\mathrm{P}_{3}\right)$ dan umur bibit 14 hari $\left(U_{1}\right)$ memperlihatkan respon yang cukup baik terhadap pertumbuhan tanaman padi ketan. Rata-rata pertumbuhan tertinggi dihasilkan dari perlakuan dosispupuk urea $300 \mathrm{~kg} \mathrm{ha}^{-1}\left(\mathrm{P}_{3}\right)$ dan umur bibit 14 hari $\left(\mathrm{U}_{1}\right)$. 
Tabel 7. Rata-rata Bobot 1000 Biji dan Bobot Gabah per Hektar pada Perlakuan Dosis Pupuk Urea dan Umur Bibit.

\begin{tabular}{ccc}
\hline $\begin{array}{c}\text { Perlakuan } \\
\text { Dosis Pupuk Urea } \\
\left(\mathrm{kg} \mathrm{ha}^{-1}\right)\end{array}$ & Bobot $1000 \mathrm{Biji}(\mathrm{g})$ & Bobot Gabah per Hektar (ton) \\
\hline 100 & 22,25 & 5,64 \\
\hline 200 & 21,76 & 5,10 \\
\hline 300 & 22,61 & 5,60 \\
\hline Uji Duncan 5\% & $\mathrm{TN}$ & $\mathrm{TN}$ \\
\hline Umur Bibit (hari) & & \\
\hline 14 & 22,17 & 5,85 \\
\hline 21 & 21,93 & 5,69 \\
\hline 28 & 22,52 & 5,32 \\
\hline Uji Duncan $5 \%$ & $\mathrm{TN}$ & $\mathrm{TN}$ \\
\hline
\end{tabular}

Keterangan: - TN : Tidak nyata.

\section{Kesimpulan}

1) Dosis pupuk urea $300 \mathrm{~kg} \mathrm{ha}{ }^{-1}\left(P_{3}\right)$ dan umur bibit 14 hari $\left(U_{1}\right)$ menunjukkan perbedaan nyata terhadap tinggi tanaman, jumlah anakan, jumlah daun, luas daun, bobot segar batang, bobot segar daun, bobot segar total, bobot kering batang, bobot kering daun, dan bobot kering total.

2) Perlakuan dosis pupuk urea $\mathrm{kg} \mathrm{ha}^{-1}\left(\mathrm{P}_{3}\right)$ dan umur bibit 14 hari $\left(\mathrm{U}_{1}\right)$ tanaman terjadi interaksi pada jumlah anakan umur $63 \mathrm{hst}$, luas daun per rumpun umur $70 \mathrm{hst}$,

3) Produktivitas gabah yang dihitung berdasarkan bobot gabah per hektar dengan dosis pupuk urea $300 \mathrm{~kg} \mathrm{ha}^{-1}\left(\mathrm{P}_{3}\right)$ 5,60 ton dan umur bibit $U_{1}$ (14 hari) 5,85 ton, menunjukkan hasil cenderung lebih baik bila dibandingkan dengan perlakuan lainnya dan memperlihatkan respon yang cukup baik terhadap pertumbuhan dan produktivitas tanaman padi ketan

4) Semakin meningkat dosis pupuk urea maka pertumbuhan tanaman akan semakin meningkat. Dan semakin muda umur transplanting bibit maka pertumbuhan tanaman juga akan semakin meningkat. 


\section{Daftar Pustaka}

Aruan dan Rita. 2010. Perbandingan Pendapatan Usahatani Padi (Oryza sativa L.) Sawah Sistem Tanam Pindah dan Tanam Benih Langsung di Desa Sidomulyo Kecamatan Anggana Kabupaten Kutai Kartanegara.

Cepy dan Wangiyana. 2011. Pertumbuhan dan Hasil Tanaman Padi (Oryza sativa L.) di Media Vertisol dan Entisol Pada Berbagai Teknik Pengaturan Air dan Jenis Pupuk. Crop Agro.

Djafar. 2002. Pengembangan dan Pengelolaan Lahan Rawa untuk Ketahanan Pangan yang Berkelanjutan. Pelatihan Nasional Manajemen Daerah Rawa Untuk Pembangunan Berkelanjutan. Palembang.

Ganl. 2003. Sistem Intensifikasi Padi (System of Rice Intensification). Pedoman Praktis Bercocok Tanam Padi Sawah dengan Sistem SRI.

Hardjowigeno, S. 1987. IImu Tanah. PT. Medyatama sarana Perkasa. Jakarta. HIm. : 73-76.

Harjadi Setyati. S.M.M. 1983. Pengantar Agronomi. PT. Gramedia Jakarta.

Hartadi, Hari, Reksohadiprodjo dan Tillman. 1997. Tabel Komposisi Pakan untuk Indonesia. Cetakan ke-4. Gadjah Mada University Press. Yogyakarta.

Haryadi. 2006. Teknologi Pengolahan Beras.Gadjah Mada University Press, Yogyakarta.

Meta, K.P. dan Kurniasari B. 2006. Teknologi Pembudidayaan Tanaman Padi. Kartika Pustaka Jaya, Bandung.

Nurhayati, Nyakpa, Lubis, Nugroho, Diha, Hong, Biley. 1986. Dasar Dasar Ilmu Tanah. Universitas Lampung, Lampung.

Putra. 2012. Pengaruh Pupuk NPK Tunggal, Majemuk, dan Pupuk Daun Terhadap Peningkatan Produksi Padi Gogo Varietas Situ Patenggang. Agrotrop. Balai Pengkajian Teknologi Pertanian Jawa Barat.

Suwardi dan Roy Efendi. 2009. Efisiensi Penggunaan Pupuk N pada Jagung KompositMenggunakan Bagan Warna Daun. BalaiPenelitian Tanaman Serelia.

Vavrina. 1998. Transplant Age In Vegetable Crops. Hort Technology. 